\title{
A comparison of four cytological sampling techniques in a genitourinary medicine clinic
}

\author{
A Szarewski, J Cuzick, M Nayagam, R N Thin
}

\begin{abstract}
Four cytological sampling techniques (the Ayre's spatula alone, the Aylesbury spatula, the Ayre's spatula in conjunction with a Cytobrush (Medscand), and the Cervex (Steriseal)) were compared when used in a genitourinary medicine clinic. Over a period of two years 6991 smears were taken. No difference was found between the methods with regard to detection of dyskaryosis, although there were significant differences in the percentages of smears containing endocervical cells.
\end{abstract}

\section{Introduction}

There has been much debate in recent years regarding the best instrument for sampling exfoliated cervical cells, and how this should be evaluated. Some studies have shown that the presence of endocervical or metaplastic cells is an important marker for an adequate smear, and when they are present, the detection of dyskaryosis is improved ${ }^{12}$ and indeed, several studies have shown such an improvement when instruments are used which give a high yield of these cells. ${ }^{34}$ These studies have been conducted mainly in general practice and it was therefore considered important to consider these questions in the setting of a genitourinary medicine clinic.

It has also been reported that the performance of individual smear takers varies with regard to the percentage of smears containing endocervical cells and also the percentage which show dyskaryotic cells. This effect has been demonstrated both between different smear takers using the same instrument, and also for individual smear takers using different instruments. ${ }^{3-5}$ In all these studies, the methods

\footnotetext{
Department of Genitourinary Medicine

A Szarewski, R N Thin

Department of Histopathology, St Thomas' Hospital, London

M Nayagam

Department of Epidemiology and Statistics, Imperial Cancer Research Fund, London J Cuzick
}

which gave the highest yield of endocervical cells also resulted in the best individual performances, and the least variation in performance between smear takers. The Cytobrush (Medscand) plus a modified Aylesbury spatula technique has, in these and other studies, been shown to give the highest yield of endocervical cells and dyskaryosis when compared to other methods. ${ }^{3-5}$

\section{Patients and methods}

Women attending the Department of Genitourinary Medicine at St Thomas' Hospital who required a cervical smear were included in the study, which took place between March 1988 and March 1990.

The four cytological sampling techniques under study were the Ayre's spatula, the Aylesbury spatula, the Cervex (Steriseal) and a combination of the Cytobrush (Medscand AB) and an Ayre's spatula (fig). When the spatulas were used alone, they were rotated once through $360^{\circ}$. The Cervex was, in accordance with the manufacturer's instructions, rotated five times through $360^{\circ}$. When the combinaion of a Cytobrush and Ayre's spatula was used, the Ayre spatula smear was taken first, followed by the Cytobrush smear: both were spread on the same slide. All smears were taken prior to cleaning the cervix with cotton wool before microbiological sampling. ${ }^{6}$

The methods were rotated on a monthly basis, and the staff of the cytology department were unaware of which was in use at any given time.

Smears were graded for the presence or absence of dyskaryosis and the presence of endocervical or metaplastic cells (which, for the purpose of analysis were considered to be equivalent indicators of transformation zone sampling). For the purposes of analysis in this study, no special category was included for smears which were negative, but showed evidence of human papillomavirus (HPV) infection. These were included the "negative" category. An inadequate smear was defined as having excess inflammatory cells or blood, or containing insufficient material for interpretation. Smears which did not contain endocervical cells, or which were air dried, were not defined as inadequate unless they also fulfilled these criteria.

The individual performances of the doctors taking 

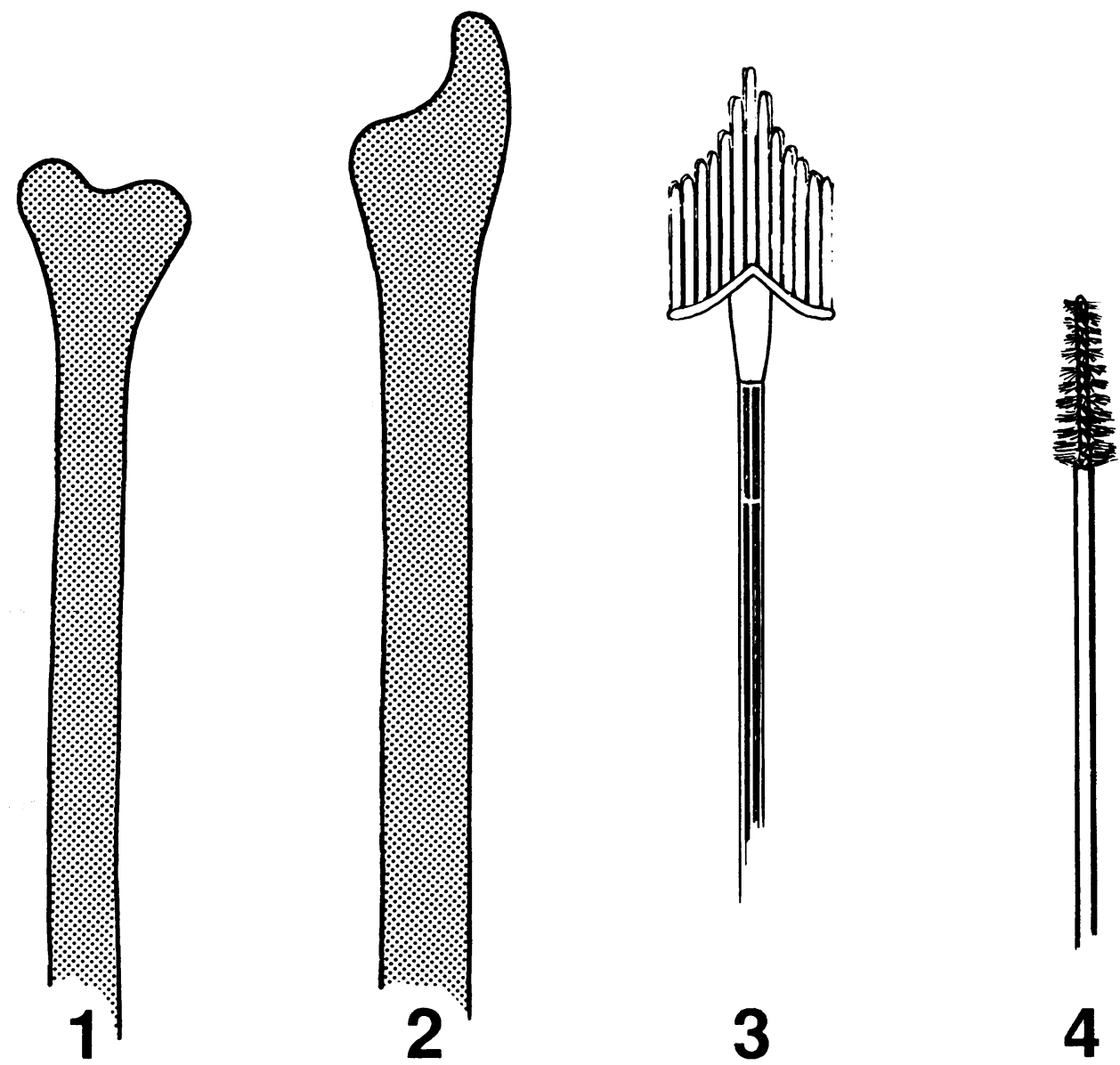

Fig Sampling devices used in the study; $1=$ Ayre spatula, $2=$ Aylesbury spatula, $3=$ Cervex, $4=$ Cytobrush .

the smears were evaluated, with regard to the presence of endocervical or metaplastic cells in their samples. The doctors were not told their results until after the study had been completed.

\section{Statistical analysis}

The data are generally reported as percentages and confidence intervals are obtained by assuming they are binomially distributed. Differences in percentages are compared by the test for a difference in proportions and significance levels are based on a normal approximation. The performance of different doctors was assessed by an analysis of variance of a logistic model of the percentage of smears without endocervical cells.

\section{Results}

During the course of the study 6991 smears were taken, with similar numbers in the four groups (table 1).
The median age of the patients was 25 years, and $89 \%$ were under the age of 35 . There was no significant difference in the ages or age distribution of the patients in the four groups.

The department has a high proportion of patients of Afrocaribbean origin. $60 \%$ of the patients in this study were of Caucasian origin, $38 \%$ of Afrocaribbean origin and $2 \%$ were of Asian or Oriental origin.

Table 1 shows the results of the study with regard to detection of dyskaryosis and presence of endocervical and metaplastic cells (referred to collectively as endocervical cells). There was a highly significant difference between the methods with regard to the yield of endocervical cells. The Cytobrush plus Ayre's spatula technique performed best in this respect, when compared with all the other methods (table 2). The Ayre used alone gave the poorest results.

The Cervex gave the highest number of inadequate smears, significantly more than either the Aylesbury or the Cytobrush plus Ayre $\left(\chi^{2}=5.89, p=0.02\right.$ and 
Table 1 Results for the four groups with regard to dyskaryosis and presence of endocervical cells

\begin{tabular}{|c|c|c|c|c|}
\hline & $\begin{array}{l}\text { Ayre } \\
n=1784\end{array}$ & $\begin{array}{l}\text { Aylesbury } \\
n=1637\end{array}$ & $\begin{array}{l}\text { Cervex } \\
n=1801\end{array}$ & $\begin{array}{l}\text { Cytobrush plus Ayre } \\
n=1769\end{array}$ \\
\hline NECS: $\underset{\%}{\text { No. }}$ & $\begin{array}{l}443 \\
24 \cdot 8 \\
(22 \cdot 8-26 \cdot 8)\end{array}$ & $\begin{array}{l}234 \\
14 \cdot 3 \\
(12 \cdot 6-16 \cdot 0)\end{array}$ & $\begin{array}{l}162 \\
9 \cdot 0 \\
(7 \cdot 7-10 \cdot 3)\end{array}$ & $\begin{array}{l}97 \\
5 \cdot 5 \\
(4 \cdot 4-6 \cdot 5)\end{array}$ \\
\hline CIN: $\underset{\%}{\text { No. }}$ & $\begin{array}{l}380 \\
21 \cdot 3 \\
(19 \cdot 4-23 \cdot 2)\end{array}$ & $\begin{array}{l}364 \\
22 \cdot 2 \\
(20 \cdot 2-24 \cdot 3)\end{array}$ & $\begin{array}{l}401 \\
22 \cdot 3 \\
(20 \cdot 3-24 \cdot 2)\end{array}$ & $\begin{array}{l}400 \\
22 \cdot 6 \\
(20 \cdot 7-24 \cdot 6)\end{array}$ \\
\hline INAD: $\underset{\%}{\text { No. }}$ & $\begin{array}{l}43 \\
2 \cdot 4 \\
(1 \cdot 7-3 \cdot 1)\end{array}$ & $\begin{array}{l}34 \\
2 \cdot 1 \\
(1 \cdot 4-2 \cdot 8)\end{array}$ & $\begin{array}{l}62 \\
3 \cdot 4 \\
(2 \cdot 6-4 \cdot 3)\end{array}$ & $\begin{array}{l}35 \\
2 \cdot 0 \\
(1 \cdot 3-2 \cdot 6)\end{array}$ \\
\hline
\end{tabular}

$95 \%$ confidence intervals in brackets. NECS $=$ no endocervical cells seen.

CIN = dyskaryosis.

Table 2 Pairwise chi square values for yield of endocardial cells by the different methods

\begin{tabular}{|c|c|c|c|c|}
\hline & Ayre & Aylesbury & Cervex & Cytobrush plus Ayre \\
\hline Ayre & & $\begin{array}{l}59.7 \\
\mathrm{p}<0.0001\end{array}$ & $\begin{array}{l}160 \cdot 2 \\
p<0.0001\end{array}$ & $\begin{array}{l}258.0 \\
p<0.0001\end{array}$ \\
\hline Aylesbury & & & $\begin{array}{l}23.6 \\
p<0.0001\end{array}$ & $\begin{array}{l}75.2 \\
p<0.0001\end{array}$ \\
\hline Cervix & & & & $\begin{array}{l}16.4 \\
p=0.0001\end{array}$ \\
\hline
\end{tabular}

Table 3 Presence of endocervical cells in negative and dyskaryotic (CIN) smears $95 \%$ confidence intervals shown in brackets

\begin{tabular}{|c|c|c|c|c|c|c|c|c|}
\hline & $\begin{array}{l}\text { Ayre } \\
\text { No. }\end{array}$ & $\%$ & $\begin{array}{l}\text { Ayl } \\
\text { No. }\end{array}$ & & $\begin{array}{l}\text { Cer } \\
\text { No. }\end{array}$ & $\%$ & $\begin{array}{l}\text { Cyt } \\
\text { No. }\end{array}$ & ${ }_{\%}$ ush plus Ayre \\
\hline NECS in negative smears & 385 & $\begin{array}{l}27 \cdot 4 \\
(25 \cdot 1-29 \cdot 8)\end{array}$ & 208 & $\begin{array}{l}16 \cdot 3 \\
(14 \cdot 3-18 \cdot 4)\end{array}$ & 145 & $\begin{array}{l}10 \cdot 4 \\
(8 \cdot 8-12 \cdot 0)\end{array}$ & 86 & $\begin{array}{l}6 \cdot 3 \\
(5 \cdot 0-7 \cdot 6)\end{array}$ \\
\hline NECS in CIN smears & 58 & $\begin{array}{l}15 \cdot 3 \\
(11 \cdot 6-18 \cdot 9)\end{array}$ & 26 & $\begin{array}{l}7 \cdot 1 \\
(4 \cdot 5-9 \cdot 8)\end{array}$ & 17 & $\begin{array}{l}4 \cdot 2 \\
(2 \cdot 3-6 \cdot 2)\end{array}$ & 11 & $\begin{array}{l}2 \cdot 8 \\
(1 \cdot 1-4 \cdot 4)\end{array}$ \\
\hline $\begin{array}{l}Z \text { value (for difference) } \\
p \text { value }\end{array}$ & \multicolumn{2}{|c|}{$-4 \cdot 87$} & \multicolumn{2}{|c|}{$-4 \cdot 42$} & 0.0002 & & \multicolumn{2}{|c|}{$-2 \cdot 77$} \\
\hline
\end{tabular}

Table 4 Performances of individual doctors with regard to presence of endocervical cells

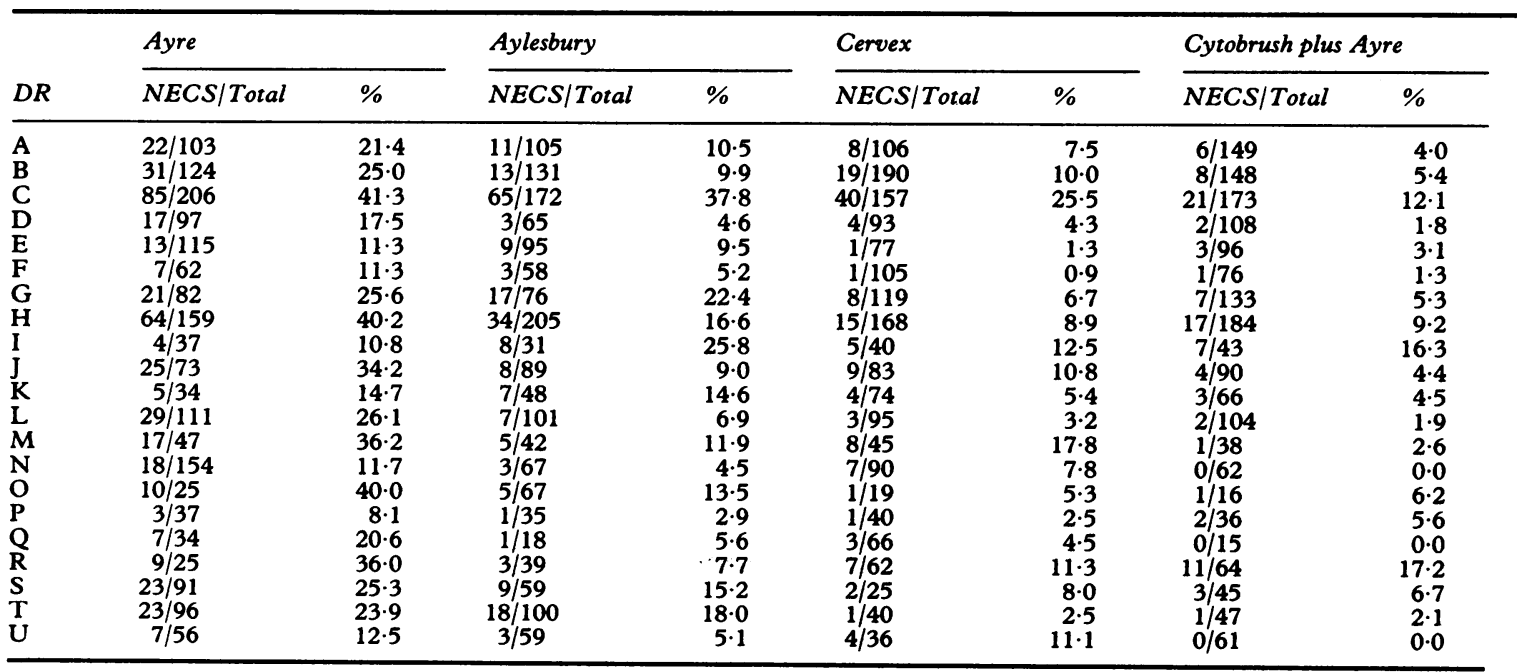


$\chi^{2}=7 \cdot 24, p=0.007$ respectively). There were no significant differences between the methods with regard to the reasons for inadequacy; the proportions of scanty, blood stained and purulent smears were the same. Air drying of smears with any of the methods was not a problem in our study.

Despite the differences in yield of endocervical cells, there was no significant difference between the methods with regard to the detection of dyskaryosis, either when taken overall or when the different grades of dyskaryosis were analysed separately. However, there was a significantly higher proportion of endocervical cells in the dyskaryotic smears than in the negative smears, and this held true for all four groups (table 3 ).

Table 4 shows the performances of the doctors taking the smears. (The performance of three doctors has been removed because they were not in the department long enough to use all four methods). It can be seen that there is wide variation in the performances of the doctors using the Ayre's spatula, with the "no endocervical cells seen" rate ranging from as high as $41.3 \%$ to $8 \cdot 1 \%$. This variation decreases slightly with the Aylesbury spatula, more so with the Cervex and is least noticable with the Cytobrush plus Ayre combination, where the range is from $17 \cdot 2 \%$ to $0.0 \%$. It can also be seen that, in general, individual doctors' performances improve in the direction Ayre, Aylesbury, Cervex, Cytobrush plus Ayre. The difference between the performances of the doctors using the four methods was significant, independent of the effects of the methods themselves $\left(\chi^{2}=273,20 \mathrm{df}, \mathrm{p}<0.0001\right)$.

\section{Discussion}

Boon et al, ${ }^{3}$ when comparing a pointed spatula used alone and in conjunction with a Cytobrush, found an increase in the presence of endocervical cells from $84 \%$ to $98 \%$. In addition, there was a doubling of the number of dyskaryotic smears (from $0.38 \%$ to $0.75 \%)$.

We also found large differences in the yield of endocervical cells, but the high dyskaryosis rate $(22 \%)$ was virtually identical for the four methods. One other study in a genitourinary medicine clinic has been reported, which compared the Aylesbury spatula with the Ayre. ${ }^{7}$ They also found a difference in the yield of endocervical cells, but no difference in dyskaryosis rates.

Women attending genitourinary medicine (GUM) clinics are known to be a high risk group for cervical neoplasia, with dyskaryosis rates of between $14 \%^{8}$ and $26 \%{ }^{9}$ reported in England and Wales respectively. In this country, accurate national statistics for the general population are not available, but two analyses, one from a general practice in Paddington ${ }^{10}$ (where the local GUM clinic had a dyskaryosis rate of
$14 \%^{8}$ ) and the other from a general practice in Wales, ${ }^{11}$ showed dyskaryosis rates of $8 \%$ and $4.5 \%$ respectively.

Our patients were significantly younger than the population referred to in national statistics. In 1987, the British Co-operative Clinical Group reported that, while national statistics showed that $55 \%$ of all smears performed in England and Wales were in women under the age of 35 years, their survey of genitourinary medicine clinics showed the figure to be $88 \% .^{9}$ In our study, the figure was $89 \%$, which is consistent with their observation. Young women are more likely to have a visible transformation zone on the ectocervix, both as a result of their age and their high oral contraceptive usage. Thus it is unlikely that sophisticated instruments, designed to sample a less accessible transformation zone, will affect the detection of dyskaryosis in this group.

It should also be noted that the doctors working in our department (and presumably most departments of genitourinary medicine) are experienced smear takers, who take many smears on a continuing basis. In these departments, women are examined in the lithotomy position, usually on couches fitted with stirrups, facilitating a good view of the cervix. These factors, and the young age of the patients are likely to combine to create what might be described as an "ideal" smear taking environment.

It is interesting to note that there was a wide variation in the performances even of our experienced doctors using the different instruments, confirming the findings of Boon and Vooijs ${ }^{345}$. If it is true that in a less ideal smear-taking environment (for example in general practice), the presence of endocervical or metaplastic cells does indeed improve the detection of dyskaryosis, then this is an important principle to be noted by those involved in screening programmes. It is certainly easier to distribute a "user independent" instrument than it is to ensure that all doctors are equally proficient in taking smears.

Although large differences were seen in the yield of endocervical cells, no significant differences were found in the dyskaryosis rates. However, if the differences in quality of smears were fully reflected in the endocervical cell rates, the observed difference of $19 \%$ in the yield of endocervical cells between the Cytobrush plus Ayre combination and the Ayre spatula alone would translate into a $2 \cdot 1 \%$ difference in dyskaryosis rates. It would not have been possible to detect such a small difference with this sample size, but it could be argued that a difference of this magnitude would not be clinically significant.

We conclude that (1) in a genitourinary medicine clinic setting, the choice between the instruments used here for cervical cytology sampling is unlikely to influence the detection rate of dyskaryosis and (2) in other facilities, the lithotomy position might be 
considered if not already in use.

We are grateful to Medscand AB, manufacturers of the Cytobrush, and Steriseal UK, former distributors of the Cervex, for their financial support.

We would also like to thank the medical and nursing staff of the Lydia department for their cooperation throughout the study, and the staff of the Cytology department.

Address for correspondence: Dr Anne Szarewski, Lydia Department, St Thomas' Hospital, London SE1 7EH, UK.

1 Elias A, Linthorst G, Bekker B, Vooijs PG. The significance of endocervical cells in the diagnosis of cervical epithelial changes. Acta Cytol 1983;27:225-9.

2 Vooijs PG, Elias A, Van der Graaf Y, Veling S. Relationship between the diagnosis of epithelial abnormalities and the composition of cervical smears. Acta Cytol 1985;29:323-8.

3 Boon ME, Alon-van-Kordelaar JJM, Rietveld-Scheffers PEM.
Consequences of the introduction of combined spatula and Cytobrush sampling for cervical cytology. Acta Cytol 1986;30:264-70.

4 Boon ME, De Graaff Guilloud JC, Rietveld WJ. Analysis of five methods for the preparation of cervical smears. Acta Cytol 1989;33:843-8.

5 Vooijs PG, Elias A, Van der Graaf Y. Poelen-vag de Berg M. The influence of sample takers on the cellular composition of cervical smears. Acta Cytol 1986;30:251-7.

6 Griffiths M, Sanderson D, Penna L. Taking cervical smears in departments of genitourinary medicine. Genitourin Med 1989;65:96-97.

7 Goorney BP, Lacey CJN, Sutton J. Ayre v Aylesbury cervical spatulas. Genitourin Med 1989;65:161-2.

8 Byrne MA, Taylor-Robinson D, Anderson MACm Mason P, Harris JRW. Value of colposcopy in sexually transmitted diseases clinic based on first year's experience. Genitourin Med 1989;65:42-45.

9 British Co-operative Clinical Group. Cervical cytology screening in sexually transmitted disease clinics in the United Kingdom. Genitourin Med 1987;63:40-43.

10 Shroff KJ, Corrigan AM, Bosher M, Edmonds MP, Sacks D, Coleman DV. Cervical screening in an inner city area: response to a call system in general practice. $\mathrm{Br} \mathrm{Med} \mathrm{J}$ 1988;297:1317-8.

11 Johnson DB, Rowlands CJ. Diagnosis and treatment of cervical intraepithelial neoplasia in general practice. $\mathrm{Br} \mathrm{Med} J$ 1989;299:1083-6.

Accepted for publication 12 September 1990. 